\title{
Continental and marine sources of organic matter and nitrogen for rías of northern Galicia (Spain)
}

\author{
Antonio Bode ${ }^{1, *}$, Manuel Varela ${ }^{1}$, Ricardo Prego ${ }^{2}$ \\ ${ }^{1}$ Instituto Español de Oceanografía, Centro Oceanográfico de A Coruña, Apdo. 130, 15080 A Coruña, Spain \\ ${ }^{2}$ Instituto de Investigaciones Marinas, CSIC, Eduardo Cabello 6, 36208 Vigo, Spain
}

\begin{abstract}
Sources of organic matter and nitrogen to the rías of Ortigueira, O Barqueiro and Viveiro (Galicia, N Spain) were traced using stable carbon and nitrogen isotopes. Samples of water, seston, benthic organisms and sediments were collected in summer 2007 and 2008. Instantaneous sources were inferred from the concentrations and isotopic composition of seston, while averaged sources over longer time scales (months) were inferred from stable isotopes in macrophytes (Ascophyllum nodosum and Fucus vesiculosus) and mussels (Mytilus galloprovincialis). Dissolved nitrate, nitrite and ammonium concentrations in surface water were low in the estuarine zone and generally increased towards the river and the open sea in all rías. Nitrite and ammonium values were generally low, suggesting low importance of in situ nitrification and denitrification processes. The concentrations of ammonium, chlorophyll, and heavy nitrogen isotopes in seston were higher only in the main river of Viveiro, suggesting local pollution. Isotopic signatures and high nitrogen concentrations in seston discharged from the wastewater treatment plants indicated incomplete removal of nitrogen. However, taking into account water discharge fluxes and the isotopic composition of all compartments analysed, all rías shared similar biogeochemical and trophic diversity and showed a low impact of anthropogenic sources at both short and long time scales. Dominance of marine waters, low river flow, and small urban population sizes in the watershed all contribute to the maintenance of the relatively pristine status of northern Galician rías.
\end{abstract}

KEY WORDS: Stable isotopes · Anthropogenic nutrients · Estuary · Macroalgae - Mussels · Galicia

\section{INTRODUCTION}

Coastal marine ecosystems integrate the varying influence of both the land and the ocean. In addition, since most human populations are concentrated on the coast, coastal ecosystems are under increasing pressures of eutrophication and pollution (Vidal et al. 1999). Differentiation of the contributions of the various sources of nutrients and organic matter is important for understanding coastal biogeochemistry and food webs, as well as for management purposes. Anthropogenic nutrients have been shown to alter coastal food webs through a change in the dominant nutrient sources (McClelland \& Valiela 1998, Castro et al. 2007). These changes lead to an acceleration of nutrient cycles and a dominance of macroalgae and phytoplankton over seagrasses.

Among the most successful methods employed for discriminating between different nutrient sources is the determination of natural abundance of stable isotopes which allows for the study of the propagation of nutrients through coastal food webs. The differential mobility of heavy versus light isotopes in chemical reactions (i.e. isotopic fractionation) causes the progressive enrichment of heavy isotopes in the reactant substance and their depletion in the reaction product (Mariotti et al. 1981). Stable isotopes characteristically label different molecules according to the chemical pathways followed in their formation. Thus, terrestrial and marine sources can be traced in 
marine systems through the analysis of the stable isotope composition of organic matter as a mixture of 2 or more end-members of distinctive isotopic signature (e.g. Peterson \& Fry 1987, McClelland \& Valiela 1998, Bode et al. 2006, Castro et al. 2007, Silva et al. 2011). Moreover, the isotopic composition of organisms reflects their nutrient inputs integrated at the time scales proportional to the renewal time of the organ considered. Thus, analysing different organisms and organs allows for the estimation of nutrient inputs at scales of days to years (Jennings et al. 2008).

At the northern limit of the eastern boundary upwelling system of the Atlantic (Barton 1998), the rías of Galicia (NW Spain) are coastal inlets originating from submersed deep river valleys sustaining high levels of biological production (Figueiras et al. 2002). The low flow of the tributary rivers implies that most of the driving nutrients are of marine origin and the resulting organic matter is recycled in the nearby shelf (Alvarez-Salgado et al. 1993, Prego 1994). Oceanographic and biogeochemical research has largely been focussed on the large and populated western rías (Rias Baixas), which are characterised by high yields of local fisheries as well as mussel and fish aquaculture (Figueiras et al. 2002). In these rías, nutrient dynamics are governed by marine circulation processes, which are ultimately driven by wind regimes producing the highest frequency and intensity of upwelling events in spring and summer (e.g. AlvarezSalgado et al. 1993, Prego 1994, Dale \& Prego 2002, Alvarez-Salgado \& Gilcoto 2004, Varela et al. 2004, Piedracoba et al. 2008). The calculated flushing times of the rías (e.g. Prego 1994, Alvarez-Salgado \& Gilcoto 2004, Dale et al. 2004) are generally short enough to prevent significant accumulation of land derived nutrients, including anthropogenic ones. However, the decrease in upwelling-favourable winds observed in recent decades may have increased the residence time of water inside the rías, thus favouring eutrophication (Alvarez-Salgado et al. 2008). In contrast, rías located in the northern coast of Galicia are smaller in size, and have different upwelling-favourable wind conditions than those in the western coast (Alvarez et al. 2009, Ospina-Alvarez et al. 2010). While the spring-summer pattern in the western coast is characterized by a high south-westward Ekman transport, Ekman transport in the northern coast is of lower magnitude and oblique to the shoreline (GómezGesteira et al. 2006). Consequently, upwelling in the north is only detected near the major capes (Prego \& Bao 1997, Alvarez et al. 2009). The main northern Galician rías (locally named 'Rías Altas') are Ortigueira $\left(38 \mathrm{~km}^{2}\right), \mathrm{O}$ Barqueiro $\left(10 \mathrm{~km}^{2}\right)$ and Viveiro $\left(27 \mathrm{~km}^{2}\right)$, which are much smaller in size than most of the western rías (125-230 $\mathrm{km}^{2}$ ). They are dominated by marine processes except at the inner estuarine zone, are partially enclosed by well developed beach barriers, and receive low fluvial discharges (Alvarez et al. 2009). In contrast to western rías, northern rías support much less urban pressure, although their human population nearly doubles during summer because they are popular vacation resorts, and are surrounded by agricultural and forestry landscapes. These characteristics of northern rías offer a unique opportunity to study nutrient and organic inputs in a relatively pristine region. Studies in the northern rías are still very scarce, and the first descriptions of their hydrography and nutrient stocks were published only recently (Alvarez et al. 2009, Xunta de Galicia 2009, Alvarez et al. 2010, Ospina-Alvarez et al. 2010).

The objective of the present study is to assess the importance of land and marine sources of organic matter and nutrients to coastal ecosystems in 3 rías of northern Galicia using stable isotopes. For this purpose, a comparative analysis was made using surface water nutrient concentrations and stable carbon (C) and nitrogen $(\mathrm{N})$ isotopes in seston samples representative of the different river, estuarine and marine environments of each ría. The study was done in summer, when maximum influence of both upwelling and anthropogenic nutrient sources is expected. This analysis aimed to illustrate the effect of upwelling on the composition of seston at the time scale of events (days). In addition, the stable isotope composition of intertidal brown algae and mussels was analysed to investigate the assimilation of terrestrial versus marine nutrients at longer time scales (months).

\section{MATERIALS AND METHODS}

\section{Water and seston}

Samples of surface water and seston were collected using an oceanographic rosette onboard RV 'Mytilus' from 15 to 17 July 2008 in the rías of Ortigueira, O Barqueiro and Viveiro (Fig. 1). Samples were also obtained from the main tributary rivers and wastewater treatment plants (WTP). At the O Barqueiro ría, particle samples were also collected from a particle interceptor trap deployed at $15 \mathrm{~m}$ (bottom depth $20 \mathrm{~m}$ ) for $24 \mathrm{~h}$. Water sampling stations were arranged from the coast to the offshore sections to represent the salinity gradient in each ría. Measurements of temperature and salinity (practical salinity scale) were concurrently done with rosette bottle sampling using a Seabird 
SBE-25 CTD and also at hourly intervals for recording tidal cycles in one station for each ría (Stn P).

Water samples for dissolved nutrients (nitrate, nitrite, ammonium, phosphate and silicate) were frozen onboard at $-20^{\circ} \mathrm{C}$ and later analyzed in the laboratory using segmented flow analysis in a Futura Autoanalyzer system (Aliance Instruments) following the procedures of Grasshoff et al. (1983). Chl a was analysed in Whatman GF/F filtered samples, extracted in $90 \%$ acetone overnight and analysed fluorometrically (Neveux \& Panouse 1987). Up to $1 \mathrm{l}$ of water was GF/F filtered to collect seston samples. Filters with

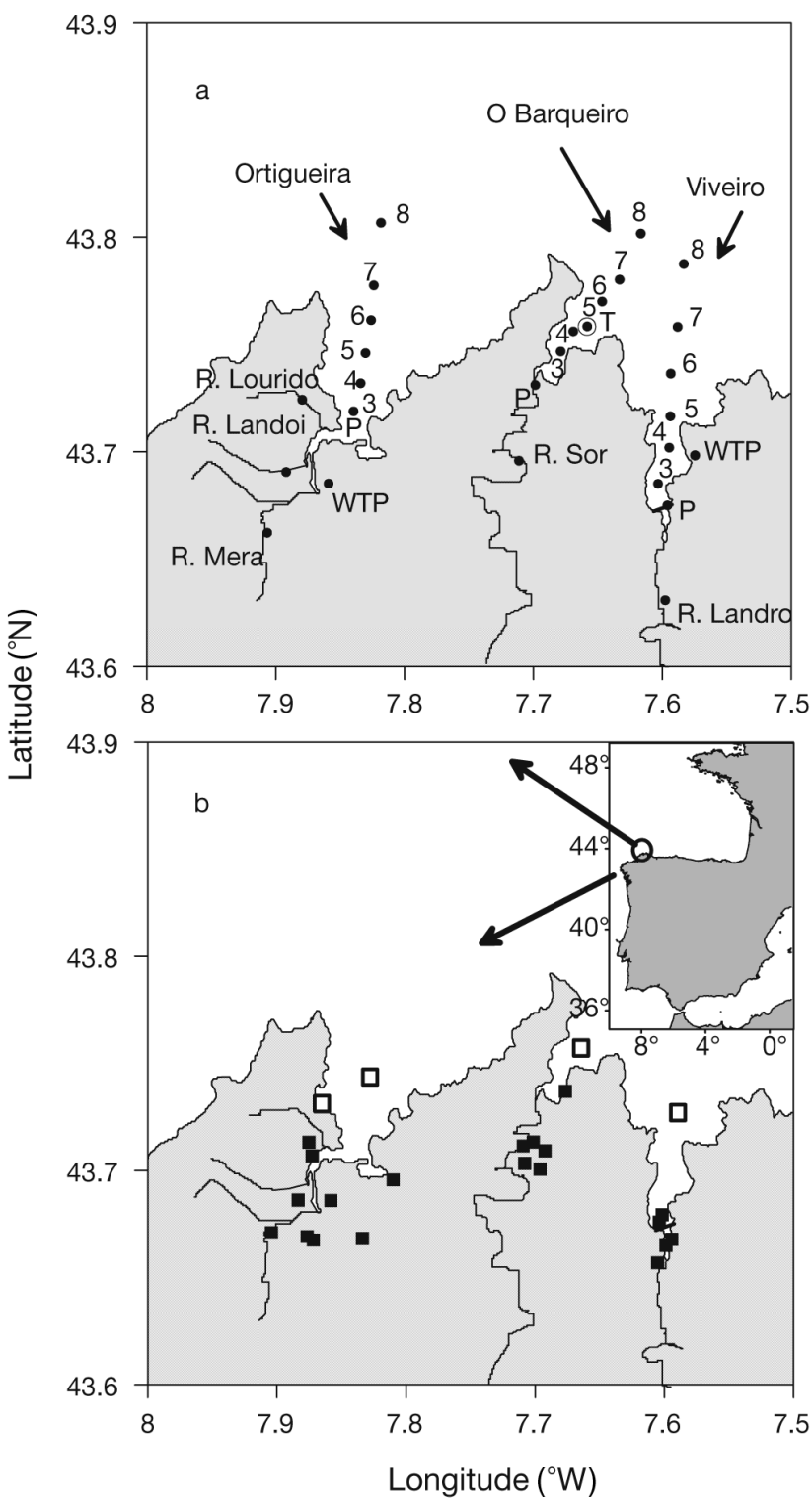

Fig. 1. Sampling sites for (a) seston and (b) sediments in the rías of Ortigueira, O Barqueiro and Viveiro, and their main tributary rivers. WTP: wastewater treatment plants; P: tidal cycle station; T: sediment trap station. (ם) estuarine sediment samples, $(\square)$ ría sediment samples seston were stored frozen $\left(-20^{\circ} \mathrm{C}\right)$ before the determination of $\mathrm{C}$ and $\mathrm{N}$ total mass and stable isotope composition. Seston was also collected at the outlet of the local WTP in Ortigueira and Viveiro (Fig. 1). Recently sedimented particles were collected in O Barqueiro (Stn T, Fig. 1) using a particle interceptor trap $(6 \mathrm{~cm}$ diam.) that was deployed for $24 \mathrm{~h}$ at $5 \mathrm{~m}$ above the bottom (Bode et al. 1998, Varela et al. 2004).

\section{Benthos and sediments}

Intertidal macrophytes (Ascophyllum nodosum and Fucus vesiculosus) and mussels Mytilus galloprovincialis were collected in all rías, where available, near the tidal cycle water sampling station (Stn P). Three individuals of each macrophyte species and 5 mussels were analysed in each ría for $\mathrm{C}$ and $\mathrm{N}$ content and stable isotope composition.

Surface $(10 \mathrm{~cm}$ deep) sediment samples from the same rías were collected using Van Veen grabs in the previous summer (July 2007), when a more detailed study of benthic communities was made. Sediment samples were stored frozen $\left(-20^{\circ} \mathrm{C}\right)$ before analysis. Samples were grouped for estuarine (surface water salinity $<35$ ) and ría (salinity $>35$ ) environments. No large interannual changes are expected in the composition of surface sediment samples as the average sedimentation rate of these rías is $\sim 1 \mathrm{~cm} \mathrm{yr}^{-1}$ (Lorenzo et al. 2007).

\section{Stable isotopes}

The natural abundance of stable $\mathrm{C}$ and $\mathrm{N}$ isotopes was determined in seston, sediments and intertidal benthic organisms. Sample manipulation and analytical procedures followed those described by Bode et al. (2006). Briefly, samples were defrosted and dried $\left(50^{\circ} \mathrm{C}, 24 \mathrm{~h}\right)$ before grinding, and encapsulated for analysis. The amounts of sample analysed ranged from $1 \mathrm{mg}$ (seston and benthic organisms) to $3 \mathrm{mg}$ of dry mass (sediments) to ensure a minimum of $10 \mu \mathrm{g}$ of $\mathrm{C}$ and $\mathrm{N}$ per sample. All benthic specimens were carefully rinsed with filtered seawater to remove debris and sediments. For macrophytes, both basal and distal parts of the thallus were analysed, while only samples from the adductor muscle of mussels were considered. Dry sediment was sieved through a $63 \mu \mathrm{m}$ mesh to collect the mud fraction for subsequent elemental and isotopic analysis. Organic $\mathrm{C}$ and $\mathrm{N}$ were analysed separately in these samples to avoid changes due to the removal of carbonates (e.g. Jacob 
et al. 2005). Sediment aliquots for organic $C$ analysis were first acidified with drops of concentrated $\mathrm{HCl}$ until no more $\mathrm{CO}_{2}$ was released (i.e. no more bubbles after $24 \mathrm{~h}$ ) and re-dried. Aliquots for $\mathrm{N}$ determination were not acidified. All samples were introduced into an isotope-ratio mass spectrometer (Thermo Finnigan Mat Delta Plus) via an elemental analyser (Carlo Erba CHNSO 1108). Isotopic results are expressed in delta notation:

$$
\delta \mathrm{X}=\left[\left(\mathrm{R}_{\text {sample }} / \mathrm{R}_{\text {std }}\right)-1\right] \times 1000
$$

where $\delta \mathrm{X}$ is $\delta^{13} \mathrm{C}$ or $\delta^{15} \mathrm{~N}, \mathrm{R}_{\text {sample }}$ is the ratio between ${ }^{13} \mathrm{C}:{ }^{12} \mathrm{C}$ or ${ }^{15} \mathrm{~N}:{ }^{14} \mathrm{~N}$ in the sample and $\mathrm{R}_{\text {std }}$ is a calibrated standard (Vienna PeeDee Belemnite Standard ${ }^{13} \mathrm{C}$ or atmospheric ${ }^{15} \mathrm{~N}$ ). The total $\mathrm{C}$ and $\mathrm{N}$ contents of samples were determined using acetanilide and urea standards. Precision (SE of 5 replicates) was better than $0.05 \%$ for isotopic determinations and better than $5 \mu \mathrm{g}$ for elemental composition of either $\mathrm{C}$ or $\mathrm{N}$. The coefficient of variation of replicated sample aliquots was always $<2 \%$.

Differences in the isotopic composition of benthic species between rías were studied by analysis of variance (ANOVA) and a posteriori Dunnett-C tests for multiple comparisons (SPSS Statistical Software). For comparative purposes, linear regression and ecosystem-wide metrics for each ría were computed from plots of $\delta^{13} \mathrm{C}$ vs. $\delta^{15} \mathrm{~N}$ for all compartments analysed. Differences in the regression lines between rías were determined using analysis of covariance (ANCOVA). Ecosystem-wide metrics were based on the niche theory and were initially applied to the analysis of food webs using stable isotope composition of individual species (Layman et al. 2007). In our approach, this procedure was intended as a standardisation of the isotopic information and an overall characterisation of food web structure and dynamics in each ría and not to determine precise trophic positions of a particular species. We included ecosystem compartments representative of basal resources seston and sediments - to take into account the variability in the isotopic signature of these sources (Schmidt et al. 2007). The metrics employed included the ranges of $\delta^{15} \mathrm{~N}(\mathrm{NR})$ and $\delta^{13} \mathrm{C}(\mathrm{CR})$, the total area encompassed by all compartments (TA), the average euclidean distance of each compartment to the centroid of the plot $(\mathrm{CD})$, the mean nearest-neighbor distance between compartments (NND) and its standard deviation (SDNND). Each of these metrics provide a measure of trophic diversity and complexity of the food web. Large values of NR generally indicate a high number of trophic levels, while large values of CR suggest a large variety of carbon sources at the base of the food web. An overall estimation of the trophic complexity (or niche space) is provided by TA, generally correlated to NR and CR. However, high values of TA can be due to a few outliers while most compartments are grouped in the centre of the plot. In this case $\mathrm{CD}$ indicates the average trophic diversity of compartments, while NND expresses its degree of packing. As NND is influenced by sample size, SDNND indicates the evenness in the distribution of trophic niches. This method is particularly suited to comparisons of estuarine food webs because the large number of potential sources in these ecosystems complicates the estimation of trophic links (Phillips \& Gregg 2003), while the dominant sources for the overall ecosystem can be summarized as the marine and terrestrial end-members, as in our case. Samples from WTP and sediment traps were not included in this analysis as they were determined only in some rías.

\section{RESULTS}

\section{Dissolved nutrients}

The variability of nutrient concentrations along the main axis of the rías indicates low river influence in all rías (Fig. 2). The gradual decrease in temperature from the inner to the outer zones, along with the rapid increase in surface salinity with values $>33$ in most of the rías (not shown), suggests the presence of upwelling waters in the shelf up to the mouths of rías. Furthermore, nutrients were not correlated with salinity (Fig. 3), except for the increase in nitrate with salinity in Ortigueira $(\mathrm{r}=0.867, \mathrm{p}<0.01)$, and there was a decrease in silicate and temperature, from high values in rivers (up to $264 \mu \mathrm{M}$ in river Landro; Fig. 4) to $\sim 1 \mu \mathrm{M}$ outside the rías. Nutrient concentrations, however, showed the different behaviours among rías (Fig. 2). Nitrate first decreased in O Barqueiro and Viveiro, reaching undetectable levels in O Barqueiro, and then increased to $\sim 1 \mu \mathrm{M}$ in mid ría with another decrease towards the open sea. In contrast, high nitrate values were found in rivers (between 32 and $47 \mu \mathrm{M}_{i}$ Fig. 4). In Ortigueira, there was a continuous increase in nitrate from the inner ría to the sea, where it reached $4.1 \mu \mathrm{M}$. Nitrite values were always low in the rías $(<0.4 \mu \mathrm{M})$ and also in the rivers $(\sim 0.2 \mu \mathrm{M})$. Ammonium was generally $<2 \mu \mathrm{M}$ in both rías and rivers but reached $\sim 4 \mu \mathrm{M}$ in the inner part of O Barqueiro and Viveiro, and in river Landro (Fig. 4). Phosphate values were generally low, but increased above $1 \mu \mathrm{M}$ in the inner zone of Ortigueira and 

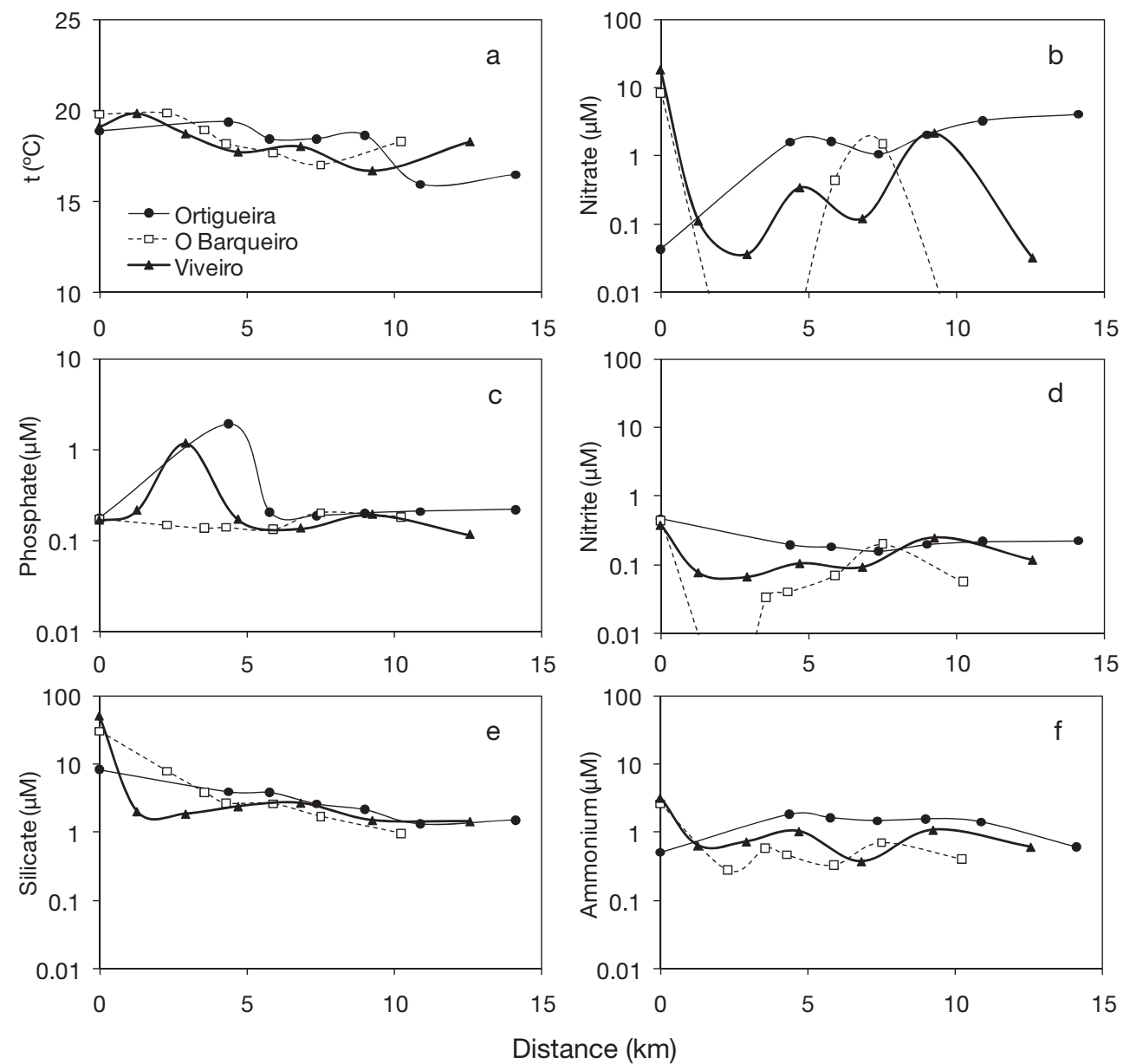

Fig. 2. Variations in (a) surface temperature $\left({ }^{\circ} \mathrm{C}\right)$, (b) nitrate, (c) phosphate, (d) nitrite, (e) silicate, and (f) ammonium along the main longitudinal axis of the rías. All nutrients are in $\mu \mathrm{M}$. Distance was measured from Stn $P$

O Barqueiro. The rivers also had values similar to those of rías except for the river Landro (2.9 $\mu \mathrm{M}_{i}$ Fig. 4$)$.

\section{Seston and sediments}

Chl a was generally highest in Ortigueira, although

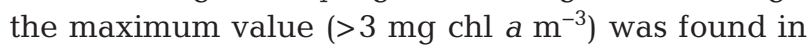
the innermost station of O Barqueiro (Fig. 5a). In contrast, most of the stations in Viveiro and O Barqueiro had low chlorophyll values $\left(<0.5 \mathrm{mg} \mathrm{chl} a \mathrm{~m}^{-3}\right)$. The rivers had comparable chl a values as the corresponding rías, except again in the river Landro where $\sim 1 \mathrm{mg}$ chl a m${ }^{-3}$ was measured (Table 1).

Notwithstanding the high values of the innermost stations in all rías, POC and PON values for all stations and rías were similar despite differences in chl a (Fig. 5c,d). However, phytoplankton contributed more to seston in Ortigueira than in the other rías, as mean $( \pm \mathrm{SD})$ POC:chl a values for Ortigueira, O Barqueiro and Viveiro stations (except Stn P) were
$5.4 \pm 2.6,17.8 \pm 7.6$ and $12.7 \pm 4.2 \mu \mathrm{mol} \mathrm{C}(\mu \mathrm{g} \mathrm{chl} \mathrm{a})^{-1}$, respectively. $\mathrm{C}: \mathrm{N}$ values increased towards the sea in O Barqueiro and Viveiro, but not in Ortigueira, where POC and PON varied less than in the other rías. Seston in rivers had POC values similar to those of the inner ría, except in O Barqueiro where the rivers had lower POC and PON than the inner ría. In contrast, river PON was lower (and C: $\mathrm{N}$ higher) than PON in the inner and middle parts of the rías (Table 1). Particles collected at the outlet of WTPs had POC and PON values that were tenfold those of rías and rivers. Local differences between WTPs were displayed by $\mathrm{C}: \mathrm{N}$ ratios, as $\mathrm{N}$ was more depleted in samples from Ortigueira than in those from Viveiro. The sediment trap in O Barqueiro revealed high fluxes of organic matter with a C:N value of 6.6 (Table 1), which is similar to seston in the nearby stations in this ría.

Sands dominate the grain composition of sediments in the rías while mud dominated in the estuarine parts (Table 2). Correspondingly, the organic content was higher in estuarine than in outer ría zones, par- 


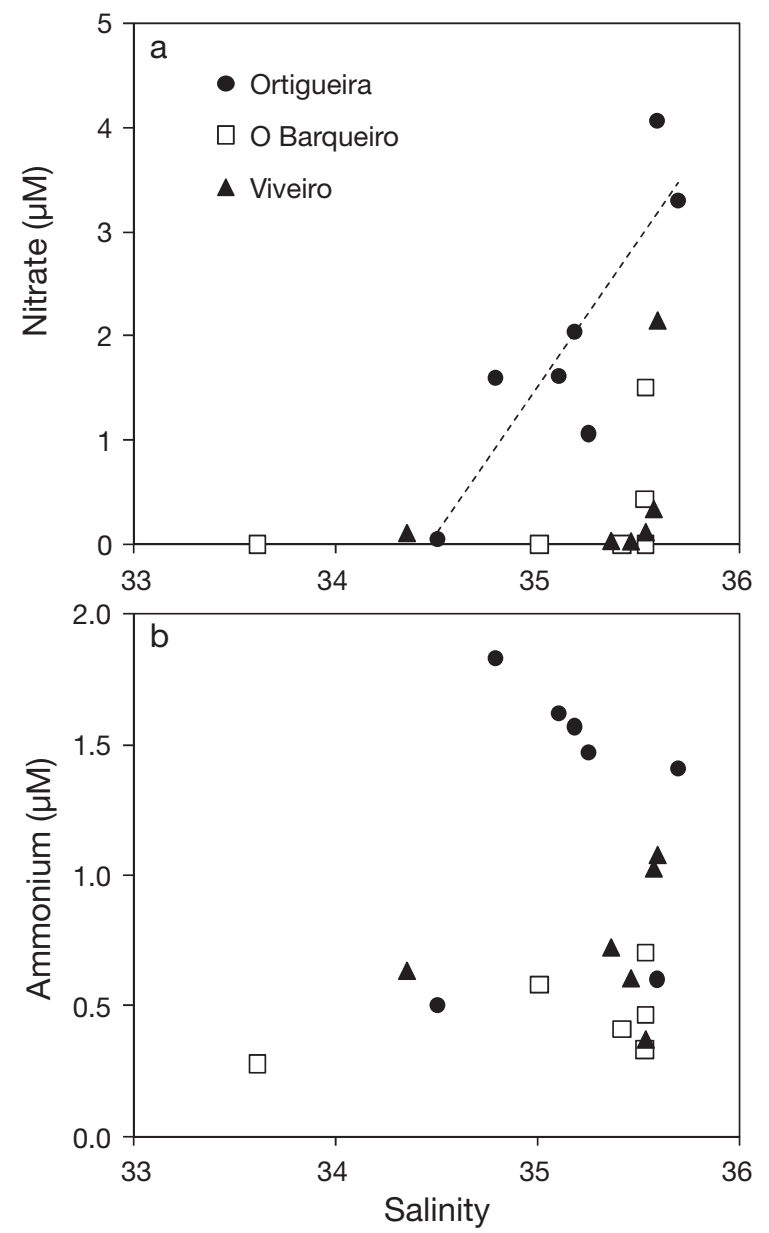

Fig. 3. Relationships between salinity (practical salinity scale) and (a) nitrate $(\mu \mathrm{M})$ or (b) ammonium $(\mu \mathrm{M})$ in surface waters of the rías. Only the regression line for nitrate in

Ortigueira was significant $(r=0.869, \mathrm{p}<0.01, \mathrm{n}=8$ )

ticularly in Viveiro. However, POC values were always $<5 \%$ by weight. Sediment C:N values were higher than those of seston in rivers and rías because of the very low $\mathrm{N}$ content of sediments $(<0.4 \%)$.

\section{Stable isotopes}

Seston $\delta^{13} \mathrm{C}$ generally decreased towards the open sea (Fig. 5e). All stations in Ortigueira had higher values than stations in the other rías while river seston was depleted in ${ }^{13} \mathrm{C}$ compared to marine seston (Table 1). In contrast, minimum $\delta^{15} \mathrm{~N}$ values in seston were generally found in central zones of the rías, except in Ortigueira (Fig. 5f). Samples from O Barqueiro were enriched in ${ }^{15} \mathrm{~N}$ by $\sim 2 \%$ relative to those from other rías and rivers, except the river Landro (Table 1). Particles from the WTP in Ortigueira were very depleted in ${ }^{15} \mathrm{~N}$ but those from the WTP in
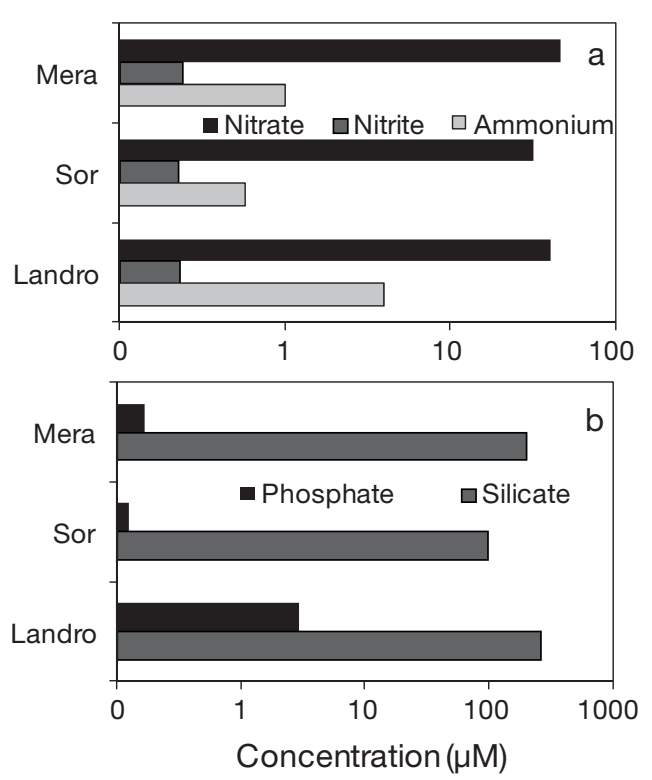

Fig. 4. Concentration of dissolved (a) nitrate, nitrite and ammonium $(\mu \mathrm{M})$, (b) phosphate and silicate $(\mu \mathrm{M})$ in surface

waters of the main tributary rivers in the study area

Viveiro were heavily enriched, displaying the largest range in $\delta^{15} \mathrm{~N}$ (Table 1). However, $\delta^{13} \mathrm{C}$ values from WTP seston were within the range found in seston from ría and river waters. Sediment trap particles had $\delta^{15} \mathrm{~N}$ values close to that of seston in the same station (5.3 vs. $5.9 \%$ ), but showed some enrichment in ${ }^{13} \mathrm{C}$ $(-22.6$ vs. $-23.8 \%$ o). Sediments in the rías were generally enriched in ${ }^{13} \mathrm{C}$ relative to seston and to sediments in the estuaries, while $\delta^{15} \mathrm{~N}$ values were more variable (Table 2). The largest differences in sediment $\delta^{15} \mathrm{~N}$ between the estuarine zone (more enriched than seston) and the ría (similar to seston) were measured in Ortigueira.

Table 1. Characteristics of seston in rivers, wastewater treatment plants (WTP) and sediment trap particles. POC and PON: particulate organic carbon and nitrogen $(\mu \mathrm{M}$, except fluxes in sediment trap), C:N: molar POC:PON ratio, $\delta^{15} \mathrm{~N}$ and $\delta^{13} \mathrm{C}$ : natural abundance of $\mathrm{N}$ and $\mathrm{C}$ isotopes

\begin{tabular}{|c|c|c|c|c|c|c|}
\hline Site & $\begin{array}{c}\mathrm{Chl} \mathrm{a} \\
\left(\mathrm{mg} \mathrm{m}^{-3}\right)\end{array}$ & $\begin{array}{l}\text { POC } \\
(\mu M)\end{array}$ & $\begin{array}{l}\text { PON } \\
(\mu \mathrm{M})\end{array}$ & $\mathrm{C}: \mathrm{N}$ & $\begin{array}{l}\delta^{13} \mathrm{C} \\
(\%)\end{array}$ & $\begin{array}{l}\delta^{15} \mathrm{~N} \\
(\%)\end{array}$ \\
\hline Lourido river & - & 10.83 & 0.67 & 16.1 & -27.6 & 3.7 \\
\hline Landoi river & - & 13.45 & 1.00 & 13.5 & -28.2 & 3.7 \\
\hline Mera river & 0.622 & 9.46 & 0.63 & 14.9 & -28.2 & 3.8 \\
\hline Sor river & 0.412 & 10.54 & 0.41 & 26.0 & -26.9 & 3.7 \\
\hline Landro river & 0.915 & 17.33 & 1.18 & 14.7 & -27.4 & 5.5 \\
\hline WTP Ortigueira & - & 177.26 & 14.26 & 12.4 & -26.2 & -4.1 \\
\hline WTP Viveiro & - & 130.14 & 21.90 & 5.9 & -25.6 & 7.5 \\
\hline Sediment trap & - & $8.65^{\mathrm{a}}$ & $1.30^{\mathrm{a}}$ & 6.6 & -22.6 & 5.3 \\
\hline${ }^{\mathrm{a}} \mathrm{mol} \mathrm{m} \mathrm{m}^{-2} \mathrm{~d}^{-1}$ & & & & & & \\
\hline
\end{tabular}



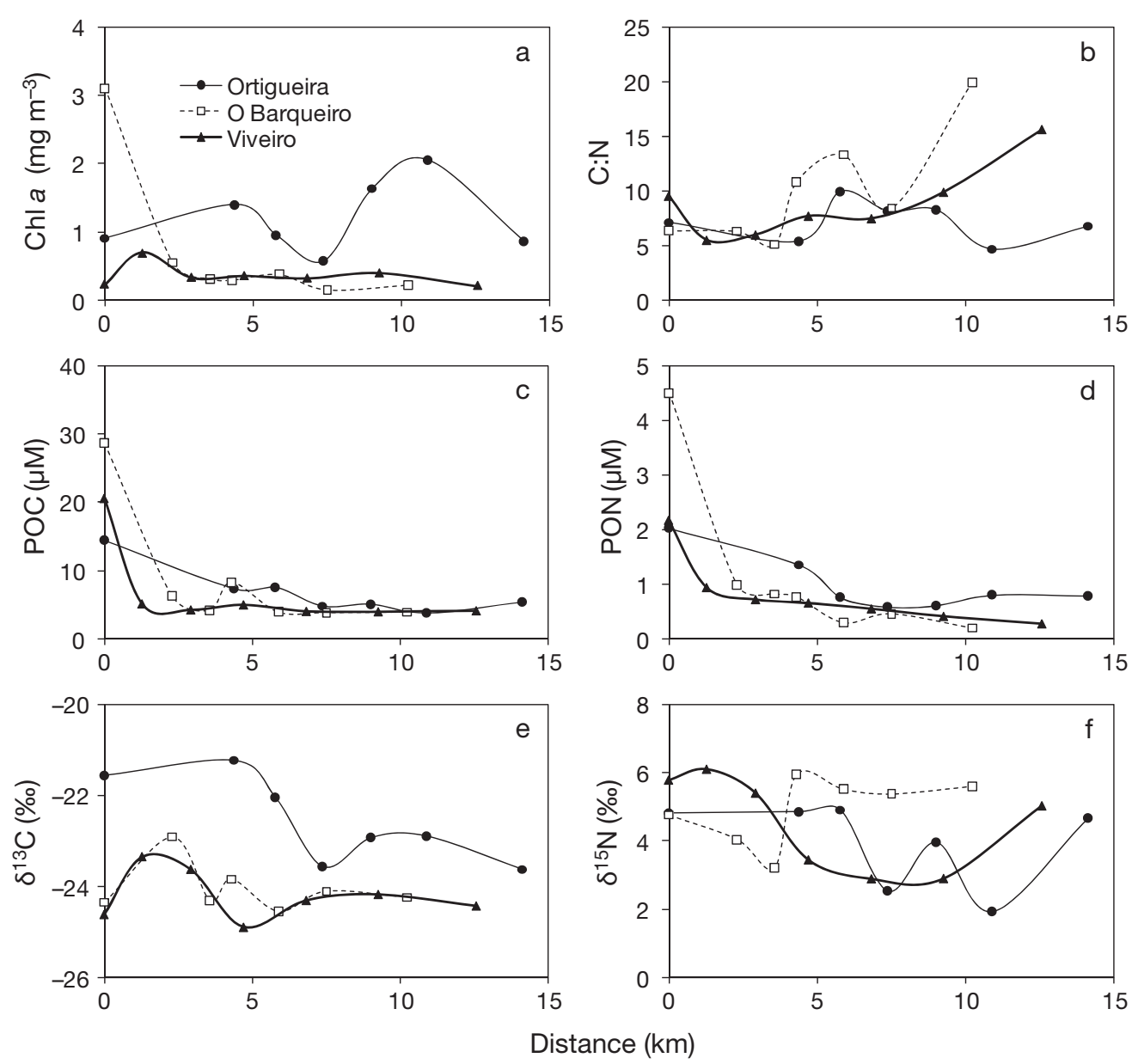

Fig. 5. Variations in surface seston variables (a) chl a $\left(\mathrm{mg} \mathrm{m}^{-3}\right)$, (b) C:N molar ratio, (c) POC ( $\left.\mu M\right),(d) P O N(\mu M),(e) \delta^{13} C(\%)$ and (f) $\delta^{15} \mathrm{~N}(\%)$ along the main longitudinal axis of the rías. Distance was measured from Stn $\mathrm{P}$

Values of $\delta^{15} \mathrm{~N}$ and $\delta^{13} \mathrm{C}$ in macroalgae also showed significant variations between species and rías (Fig. 6a-d). Fucus vesiculosus was more enriched in heavy $\mathrm{C}$ and $\mathrm{N}$ isotopes than Ascophyllum nodosum in O Barqueiro but not in Viveiro (ANOVA; $\mathrm{p}=0.002$ for $\delta^{15} \mathrm{~N}, \mathrm{p}=0.035$ for $\delta^{13} \mathrm{C}, \mathrm{n}=6$ ). In F. vesiculosus, differences between rías were only significant for $\delta^{15} \mathrm{~N}$ with maximum values in $\mathrm{O}$ Barqueiro, while mean $\delta^{13} \mathrm{C}$ values were equivalent in all rías. In contrast to macroalgae, mussels displayed significantly higher $\delta^{15} \mathrm{~N}$ and $\delta^{13} \mathrm{C}$ values in Viveiro than in the other rías (Fig. 6e,f).

\section{Overall isotope composition}

$\mathrm{C}$ and $\mathrm{N}$ isotopes were significantly correlated in all rías (covariate $\delta^{15} \mathrm{~N}$ in Table 3). The resulting regression lines (Fig. 7) indicated a similar relationship in all cases, since there were no significant differences in slopes (interaction between factor ría and covariate in
Table 3) or intercepts (factor ría in Table 3). These results suggest that the studied rías do not differ in the biogeochemical processing of $\mathrm{C}$ and $\mathrm{N}$ sources.

The bidimensional space delimited by all isotopic determinations was higher in Ortigueira than in the other rías (TA in Table 4). This was due to the larger range of both $\delta^{15} \mathrm{~N}$ and $\delta^{13} \mathrm{C}$ in Ortigueira, which was caused by the high value $(8 \%)$ of $\delta^{15} \mathrm{~N}$ in estuarine sediments (Table 2) and the low values of $\delta^{13} \mathrm{C}$ in riverine seston (Table 1 ). These results together indicate multiple sources of $\mathrm{C}$ at the base of the food web and, in principle, a more complex food web in Ortigueira than in the other rías. Conversely, O Barqueiro and Viveiro samples occupied equivalent areas in the isotopic space, but Viveiro had the lowest range in $\delta^{15} \mathrm{~N}$ (NR in Table 4), suggesting less trophic complexity. The mean distance of samples to the centroid of the isotopic area increased slightly from Ortigueira to Viveiro, while mean distance and variability between neighbouring samples was highest in the former due to extreme values in seston and 
Table 2. Characteristics of superficial sediments in the study area. Samples were grouped as ría or estuarine. \%mud: fraction $<63 \mu \mathrm{m}$ by weight, \%POC and \%PON: percent particulate organic carbon and nitrogen (by weight), C:N: molar POC:PON ratio, $\delta^{15} \mathrm{~N}$ and $\delta^{13} \mathrm{C}$ : natural abundance of nitrogen and C isotopes (\%). Data are mean $\pm \mathrm{SE}$ (number of samples in parentheses)

\begin{tabular}{|c|c|c|c|c|c|c|c|c|c|c|c|c|c|c|c|c|c|}
\hline Group & \multicolumn{3}{|c|}{$\%$ mud } & \multicolumn{3}{|c|}{$\%$ POC } & \multicolumn{3}{|c|}{$\%$ PON } & \multicolumn{3}{|c|}{$\mathrm{C}: \mathrm{N}$} & \multicolumn{3}{|c|}{$\delta^{15} \mathrm{~N}$} & \multicolumn{2}{|c|}{$\delta^{13} \mathrm{C}$} \\
\hline \multicolumn{18}{|c|}{ Ortigueira } \\
\hline Ría & 36.0 & \pm 32.0 & (3) & 3.13 & \pm 0.13 & (3) & 0.16 & \pm 0.14 & (3) & 10.8 & \pm 1.0 & (3) & 2.5 & \pm 2.0 & (3) & -19.4 & \pm 2.6 \\
\hline Estuary & 100.0 & - & (1) & 0.95 & \pm 0.53 & (2) & 0.10 & \pm 0.03 & (2) & 9.7 & \pm 2.5 & (2) & 8.0 & \pm 1.7 & (2) & -18.6 & \pm 1.1 \\
\hline \multicolumn{18}{|c|}{ O Barqueiro } \\
\hline Ría & 11.5 & - & (1) & 3.33 & - & (1) & 0.04 & - & (1) & 10.7 & - & (1) & 5.3 & - & (1) & -16.8 & - (1) \\
\hline Estuary & 100.0 & - & (1) & 2.39 & - & (1) & 0.14 & - & (1) & 13.3 & - & (1) & 4.2 & - & (1) & -19.8 & $-\quad(1)$ \\
\hline \multicolumn{18}{|l|}{ Viveiro } \\
\hline Ría & 4.9 & - & (1) & 2.53 & - & (1) & 0.03 & - & (1) & 9.6 & - & (1) & 5.0 & - & (1) & -17.5 & - (1) \\
\hline Estuary & 84.5 & \pm 15.5 & (4) & 1.44 & \pm 1.03 & (4) & 0.26 & \pm 0.09 & (4) & 14.5 & \pm 1.2 & (4) & 5.2 & \pm 0.3 & (4) & -20.8 & \pm 1.2 \\
\hline
\end{tabular}
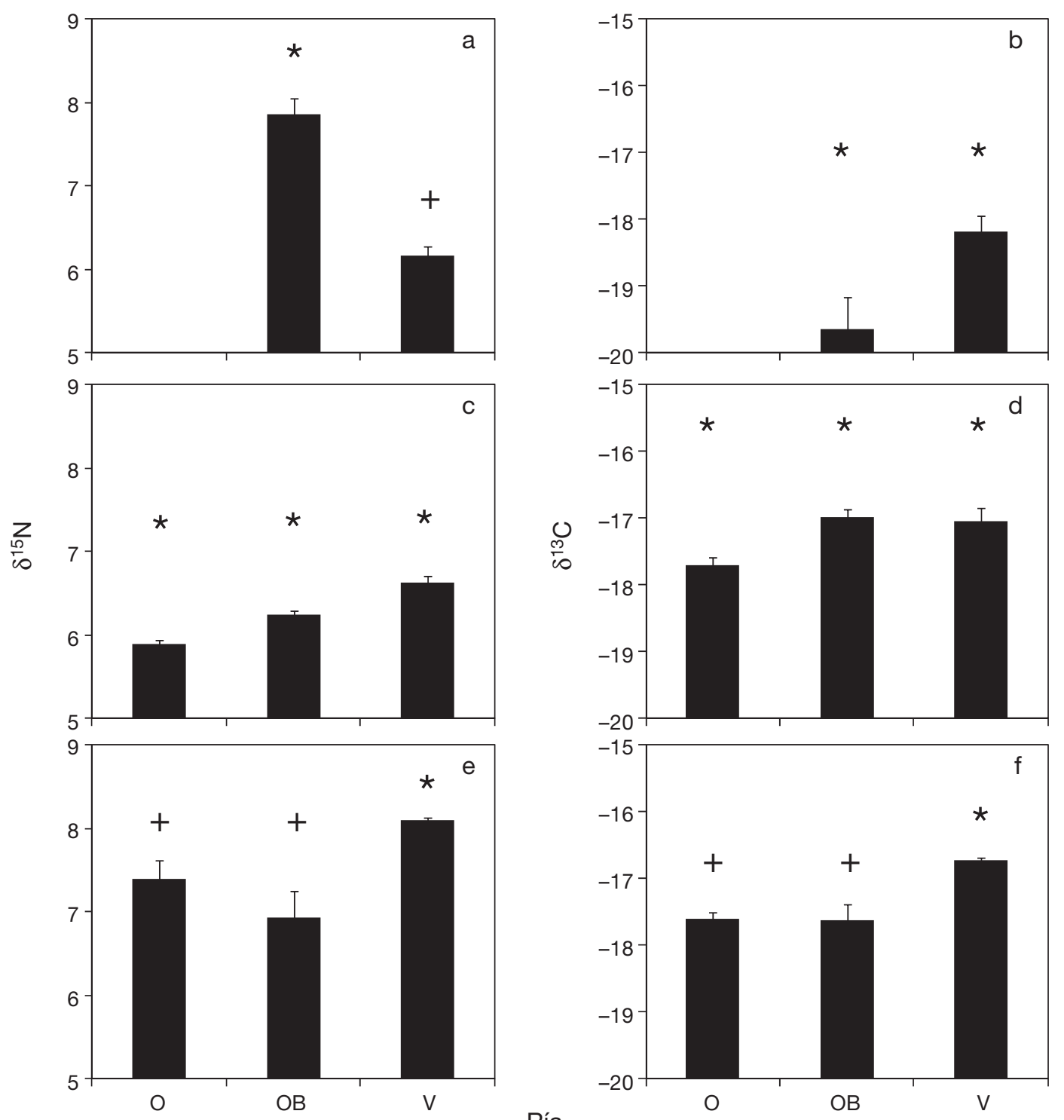

Ría

Fig. 6. Mean $( \pm \mathrm{SE}) \delta^{15} \mathrm{~N}$ and $\delta^{13} \mathrm{C}(\%)$ in $(\mathrm{a}, \mathrm{b})$ Fucus vesiculosus, $(\mathrm{c}, \mathrm{d})$ Ascophyllum nodosum and (e,f) Mytilus galloprovincialis collected in the rías. O: Ortigueira; OB: O Barqueiro; V: Viveiro. $\left({ }^{*},+\right)$ significantly different means (ANOVA and Dunnett-

C test; $\mathrm{p}<0.05, \mathrm{n} \geq 6$ ) 
Table 3. Analysis of covariance (ANCOVA) comparing the regression lines between $\delta^{13} \mathrm{C}$ and $\delta^{15} \mathrm{~N}$ (covariate) when grouped by rías (fixed factor)

\begin{tabular}{|lrrrrc|}
\hline Factor & \multicolumn{1}{c}{$\mathrm{SS}$} & $\mathrm{df}$ & $\mathrm{MS}$ & \multicolumn{1}{c|}{$F$} & $\mathrm{p}$ \\
\hline Constant & 4364.6 & 1 & 4364.6 & 458.7 & 0.000 \\
Ría & 11.0 & 2 & 5.5 & 0.6 & 0.564 \\
$\delta^{15} \mathrm{~N}$ & 352.9 & 1 & 352.9 & 37.1 & 0.000 \\
Ría $\times \delta^{15} \mathrm{~N}$ & 11.3 & 2 & 5.7 & 0.6 & 0.553 \\
Error & 999.0 & 105 & 9.5 & & \\
Total & 43141.2 & 111 & & & \\
\hline
\end{tabular}

estuarine sediments. Minimum values of both mean and variability of distance to neighbouring samples were found in $\mathrm{O}$ Barqueiro. Thus, the apparent larger complexity of the food web in Ortigueira can be attributed to the extreme values measured in seston and sediments, while most of the other samples were more closely packed in the trophic space (CA, NND and SDNND values) than in the other rías. O Barqueiro displayed an intermediate degree of trophic diversity but had the highest similarity between samples, while Viveiro had a relatively high value of mean trophic diversity (CA value) but was less tightly packed than O Barqueiro (Fig. 7) due to a large variability of samples (large distance between neighbouring samples, Table 4).

\section{DISCUSSION}

The present study documents for the first time the differential inputs of organic matter and $\mathrm{N}$ in 3 of the less studied rías in Galicia. Among the multiple possible sources (rivers, runoff, urban and agricultural wastewater, seawater inputs), our results support a dominant role of marine sources in determining the composition of organic matter in seston, sediments and key benthic species.

\section{Sources at short time scales}

Upwelling in this region is generally associated with the western coast of Galicia (e.g. Barton 1998) but it also occurs in the northern coast (Alvarez et al. 2009). A detailed analysis of the cruise in 2008 revealed significant upwelling effects in the northern Galician shelf (Ospina-Alvarez et al. 2010), as indicated by the presence of cold waters, particularly near Ortigueira (Fig. 2). Previous studies also indicated that upwelling is a prevalent characteristic of this shelf even in winter (Alvarez et al. 2009). However,
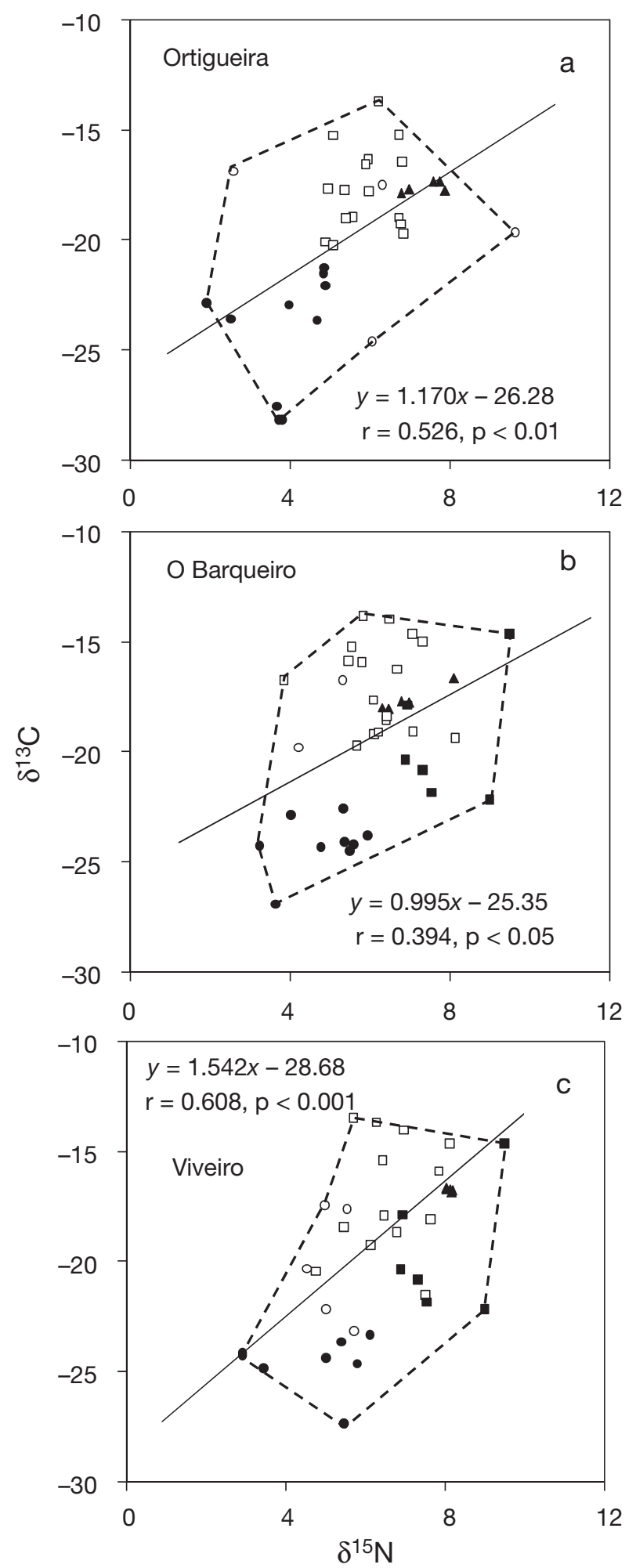

Fig. 7. Linear regression between $\delta^{15} \mathrm{~N}$ and $\delta^{13} \mathrm{C}(\%)$ in all compartments sampled for (a) Ortigueira, (b) O Barqueiro and (c) Viveiro rías. (•) seston, (O) sediments, ( $\mathbf{\square})$ Fucus vesiculosus, ( $\square$ ) Ascophyllum nodosum, (\) Mytilus galloprovincialis. The polygons (dashed line) indicate the area used in the computation of ecosystem-wide metrics (Table 4) 
Table 4. Metrics of ecosystem-wide stable isotope composition as displayed in Fig. 7. NR: $\delta^{15} \mathrm{~N}$ range; CR: $\delta^{13} \mathrm{C}$ range; TA: total area of polygon in Fig. 7; CD: mean Euclidean distance to centroid; NND: mean nearest-neighbour Euclidean distance; SDNND: standard deviation of NND

\begin{tabular}{|lcccccc|}
\hline Ría & NR & CR & TA & CD & NND & SDNND \\
\hline Ortigueira & 7.68 & 14.47 & 61.70 & 0.05 & 1.38 & 1.40 \\
O Barqueiro & 6.29 & 13.06 & 56.28 & 0.06 & 1.14 & 0.86 \\
Viveiro & 5.28 & 13.88 & 54.88 & 0.07 & 1.21 & 1.08 \\
\hline
\end{tabular}

the nutrient enrichment provided by upwelling in these rías differs from that observed in other rías off the western coast where upwelling waters often reach the innermost and shallow zones, with a large fertilizing effect on the rías by injection of new nutrients (Alvarez-Salgado et al. 1993, Prego 1994, Piedracoba et al. 2008). Moreover, the outflow of the organically rich upper layer to the nearby shelf allows for rapid in situ remineralisation of nutrients that re-enter the ría with the conveyor-belt circulation typical of upwellingdownwelling cycles. In contrast, upwelling waters in the outer reaches of the northern rías are restricted to the shelf (Ospina-Alvarez et al. 2010). In this case, the effect of upwelling on nutrient dynamics is mainly related to the retention of coastal, mesohaline waters within the rías, where the existing nutrients can sustain relatively high levels of primary production. This is indicated by the nutrient concentrations in most of these rías, which are lower than those typical of recently upwelled waters ( $>8 \mu \mathrm{M}$ nitrate; Alvarez-Salgado et al. 1993, Prego et al. 1999). The resulting phytoplankton biomass, as indicated by chlorophyll concentrations, was also lower than those observed in western rías after upwelling (e.g. Varela et al. 2004). In situ remineralisation appears to be of low importance, at least for the upper photic layer, as the observed concentrations of nitrite and ammonium in surface waters were generally low (Fig. 2). Exceptions were some stations in O Barqueiro where nitrite concentrations exceeded those of nitrate that had undetectable levels $(<0.01 \mu \mathrm{M})$. No significant benthic remineralisation can be expected because of the relatively low organic matter content in sediments, even in estuarine areas (Table 2), and the high oxygen content of the waters in these rías (Xunta de Galicia 2009).

Despite the generally higher measured nutrient concentrations in rivers than in the rías, the overall effect of river water in the nutrient enrichment of the rías can be considered small for 2 reasons. First, river flow is low compared to the water volume exchanged by tides. The mean annual flows of the Mera, Sor and
Landro rivers are $4.2,6.0$ and $7.1 \mathrm{~m}^{3} \mathrm{~s}^{-1}$, respectively (Río-Barja \& Rodríguez-Lestegás 1996), with summer values being much smaller (Ospina-Alvarez et al. 2010). In contrast, the volume of seawater exchanged exceeds river water by 50 - (neap tides) to 200 -fold (spring tides) in these rías (Xunta de Galicia 2009). In these conditions, the maximum nutrient concentrations measured in rivers $(46.9 \mu \mathrm{M}$ nitrate in river Mera and $2.9 \mu \mathrm{M}$ phosphate in river Landro) are rapidly diluted in surface waters of the innermost zone of the ría, where nitrate was almost undetectable (Fig. 2). Furthermore, nutrient concentrations in this study were not linearly related to salinity, except for the positive correlation found in Ortigueira, which is related to the stronger influence of upwelling in this ría. This lack of linearity contrasts with the negative linear relationships between major nutrients (nitrate and phosphate) found in a previous study of the same rías but restricted to the partially mixed, estuarine waters (Xunta de Galicia 2009). Both results support the rapid mixing of fresh and marine waters in the inner zone of these rías with consequent dilution of riverine nutrients. Local accumulation of floating detritus, however, may occasionally produce relatively high values of some nutrients (e.g. $\sim 1 \mu \mathrm{M}$ phosphate in the inner zone of Ortigueira and Viveiro).

Second, the influence of anthropogenic nutrients or organic matter appears small when compared to concentration values observed in rivers flowing through more populated areas. Extrapolation of nutrient measurements in partially mixed, estuarine waters of these rías to zero salinity (as a proxy for nutrient load in river waters) led to the conclusion of an increase in excess $\mathrm{N}$ from Ortigueira to Viveiro in a previous study (Xunta de Galicia 2009). The excess nutrients were attributed to increasing agricultural and urbanization pressures, but actual concentration values were typical of uncontaminated rivers in this region (Prego \& Vergara 1998, Gago et al. 2005). In the present study, ammonium and nitrite concentrations in rivers were quite low $(0.2 \mu \mathrm{M}$ nitrite and up to $4 \mu \mathrm{M}$ ammonium) compared to values measured in rivers and estuaries with strong anthropogenic pressure (Paerl et al. 2006, Castro et al. 2007). While a linear decrease in ammonium with salinity would be expected if there were sustained large inputs of $\mathrm{N}$ derived from manure, ammonium was not related to salinity (Fig. 3) and maximum values (besides those of rivers) were measured in partially mixed waters (Ortigueira) or outside the rías (O Barqueiro, Viveiro). These local maxima in ammonium, along with high phosphate values measured in this study in the 
Landro river and in the nearby estuarine area, however, point to local sources of anthropogenic nutrients for the ría of Viveiro. This agrees with previous reports of local enrichments in the estuarine zone of this ría (Xunta de Galicia 2009), while all the studied rías generally seem to receive small loads of riverine and runoff nutrients.

The same small influence may also apply to the input of organic matter from terrestrial sources, as chlorophyll in the rivers was $<1 \mathrm{mg} \mathrm{m}^{-3}$, and was generally equivalent to that found in the rías. An exception was again found in the Landro river, which had higher phytoplankton biomass than the ría likely due to the excess nutrients. Phytoplankton from the ría was the main component of seston in Ortigueira, as deduced from low POC:chl a values, while other C sources (i.e. heterotrophic plankton and detritus) were more important in the other rías. Furthermore, $\mathrm{C}: \mathrm{N}$ values of seston in the inner zone of all rías were close to 6.6, which is characteristic of phytoplankton cells. In contrast, estuaries with high influence of land vegetation have high C:N ratios reflecting the large content of structural carbohydrates of terrestrial plants (Keefe 1994). The increase in C:N values towards the shelf is indicative of food web processing of phytoplankton-derived matter. Similarly, the C:N values of sediments, although higher than those of seston, were generally characteristic of degradation of organic matter of mainly planktonic origin. Sediments with C:N >10 can be expected if most of the organic matter comes from macrophytes and values $>20$ are generally associated with detritus from vascular and terrestrial plants (Cifuentes et al. 1988).

The results obtained for stable isotopes confirmed the dominant marine origin of $\mathrm{N}$ and the planktonic origin of organic matter in the rías. Isotopic enrichment in $\mathrm{N}$ of seston from the ría generally showed values between 4 and $6 \%$, which is typical of coastal and shelf waters in the N Atlantic (Tucker et al. 1999, McKinney et al. 2010) and similar to values reported for Galicia (Bode et al. 2006). This is consistent with a predominant use of marine inorganic nitrogen, with $\delta^{15} \mathrm{~N}$ generally between $5 \%$ (nitrate; Liu \& Kaplan 1989) and $7 \%$ (ammonium; Holmes et al. 1998), in primary production. In contrast, $\mathrm{N}$ from rivers or aquifers not affected by sewage or manure have $\delta^{15} \mathrm{~N}$ values of $\sim 4 \%$ (Kendall 1998), which is very similar to those measured in riverine seston in this study (Table 1). In the estuarine zone (salinity $<35$ ), the application of a simple mixing model from 2 sources using end-member $\delta^{15} \mathrm{~N}$ values of $4 \%$ (river) and 6\% (sea) (e.g. Phillips \& Gregg 2003) revealed that $\mathrm{N}$ from the river would have maximum contributions of 60,80 and
$3 \%$ to seston samples in Ortigueira, O Barqueiro and Viveiro, respectively. Contributions of WTP N would be even lower, as the application of $\delta^{15} \mathrm{~N}$ values measured in WTP seston (Table 1) and those of marine waters to the 2-source mixing model indicated maximum WTP contributions of $12 \%$ (Ortigueira) and $3 \%$ (Viveiro). Similarly, using the measured $\delta^{13} \mathrm{C}$ in seston, we estimated organic $\mathrm{C}$ contributions from rivers of up to $6 \%$ (O Barqueiro) and $8 \%$ (Viveiro), while WTP contributions would reach $18 \%$ in Viveiro. All seston samples in Ortigueira were enriched in ${ }^{13} \mathrm{C}$ compared to either river or WTP seston, suggesting a major contribution of diatoms in this ría during the study. Marine diatoms are characteristically ${ }^{13} \mathrm{C}$-enriched compared to other phytoplankton (Fry \& Wainright 1991) and high $\delta^{13} \mathrm{C}$ values were measured in Galicia during plankton blooms (Bode et al. 2006). The existence of a diatom bloom in Ortigueira is consistent with the relatively high nutrient (Fig. 2) and chlorophyll concentrations (Fig. 5) and thermohaline properties characteristic of upwelling (Ospina-Alvarez et al. 2010). Moreover, phytoplankton counts from samples of O Barqueiro collected during this study revealed the general dominance of diatoms over other groups, although no counts were made in Ortigueira (Ospina-Alvarez et al. 2010).

The low contribution of residual waters to both $\mathrm{N}$ and organic $\mathrm{C}$ sources for the rías, despite their high concentrations (Table 1) may be explained by the relatively low average flows at WTPs (1800 and $6239 \mathrm{~m}^{3}$ $\mathrm{d}^{-1}$ at Ortigueira and Viveiro, respectively) (http:// augasdegalicia.xunta.es/). However, $\delta^{15} \mathrm{~N}$ values observed in seston indicate large differences between WTPs in the efficiency of $\mathrm{N}$ removal, while POC, PON and $\delta^{13} \mathrm{C}$ values of samples from both WTPs were similar. The negative $\delta^{15} \mathrm{~N}$ value observed in Ortigueira is characteristic of raw residual waters directly discharged into the ría (e.g. $-3.87 \%$; Daskin et al. 2008), while the value measured in Viveiro agrees with values observed in seston from WTPs with effective biological reactors for $\mathrm{N}$ remineralisation (e.g. $7 \%$; Piola et al. 2006). The enrichment of heavy isotopes in seston released from such WTPs would be the result of intense isotopic fractionation during ammonification and nitrification in the reactors, as the preferential production of ${ }^{14} \mathrm{~N}$ ammonium and nitrate would leave the remaining organic $\mathrm{N}$ enriched in ${ }^{15} \mathrm{~N}$. In contrast to $\mathrm{N}, \mathrm{C}$ isotope signatures of WTP seston ( - $26 \%$; Table 1$)$ are consistent with an effective removal of organic C in WTPs with tertiary (biological) treatments (Piola et al. 2006), as untreated waters are relatively enriched in ${ }^{13} \mathrm{C}$ (Kwak \& Zedler 1997). Therefore, although both WTPs have 
biological reactors for organic matter remineralisation, our results point to local differences in their performance due to differences in either the nature of the treated wastewaters (i.e. the proportion of urban and industrial residuals) or their capacity (much larger in Viveiro).

\section{Sources at long time scales}

Sediments continuously receive organic matter inputs from seston and thus integrate the contributions from the different terrestrial and marine sources at time scales longer than those in seston. The measured sedimentation rates in the sediment trap deployed in this study (Table 1) are low compared to those of western Galician rías (Varela et al. 2003, 2004) and coastal waters (Bode et al. 1998, Olli et al. 2001). Even if it comes from a single date, this result implies a reduced input of organic matter to sediments with low organic content (Table 2). Furthermore, the relatively low $\delta^{15} \mathrm{~N}$ in sediments compared to that of seston indicates that nitrification and denitrification processes are of low importance except in the estuarine zone of Ortigueira, where mean values exceeded those of seston. Nitrification preferentially removes light isotopes as nitrite and nitrate and leaves the reactant, in this case sedimentary organic matter, enriched in heavy isotopes (Mariotti et al. 1981). However, the measured $\delta^{15} \mathrm{~N}$ values of sediments are consistent with values measured in other nonpolluted estuaries (Castro et al. 2007). In contrast, high nitrification rates were estimated in bottom layers of the more productive ría of Vigo in south-western Galicia (Alvarez-Salgado \& Gilcoto 2004). Denitrification $\left(\mathrm{N}_{2} \mathrm{O}\right.$ production from nitrate) would have caused the depletion of heavy isotopes in the reactant (Mariotti et al. 1981) but also an enrichment in the organic matter remaining in the sediment. Therefore, the sediments of northern rías are indicative of moderate to low denitrification and remineralisation of organic N. C isotope signatures and $\mathrm{C}: \mathrm{N}$ values suggest, however, that the organic $\mathrm{C}$ remaining in the sediments is highly processed. Mean $\delta^{13} \mathrm{C}$ was generally above $-20 \%$ (Table 2 ), exceeding values typical of estuaries with large organic load and fresh detritus (Thornton \& McManus 1994, Graham et al. 2001). The high excess of organic C, as found in other coastal inlets (e.g. Cook et al. 2004, Silva et al. 2011), suggest the presence of either hydrocarbons or, more likely, remains of terrestrial plants. Microbial respiration of labile C (i.e. carbohydrates, lipids, amino acids) would have preferentially removed the light $\mathrm{C}$ isotopes and thus enriched the remaining non-labile fraction.

Up the food web, isotopic signatures confirm the dominant use of marine $\mathrm{N}$ sources. Macroalgae and mussels were only moderately enriched in ${ }^{15} \mathrm{~N}$ compared to seston, and mean $\delta^{15} \mathrm{~N}$ values were even lower than those found in the same species located in rías with larger human pressure. The ría de $\mathrm{A}$ Coruña, for instance, supports an urban population of $>240000$ inhabitants, while Viveiro, the most populated ría in our study, supports a population barely reaching 17000 (Spanish Official Population Census, www.ine.es). Values of mean $( \pm \mathrm{SE}) \delta^{15} \mathrm{~N}$ in Ascophyllum nodosum in A Coruña were $11.4 \pm 0.2 \%$ (Bode et al. 2006), while those in our study were much lower $(6.6 \pm 0.1,5.9 \pm 0.0$ and $6.2 \pm 0.1 \%$ for Viveiro, Ortigueira and $\mathrm{O}$ Barqueiro, respectively). Muscular tissues of molluscs, like those of the analysed mussels, displayed low variability in $\delta^{15} \mathrm{~N}$ through the year, thus reflecting an integrated animal diet despite seasonal variations in food sources and metabolism (Lorrain et al. 2002, Deudero et al. 2009). In Viveiro, the significant isotopic enrichment of mussels suggests a persistent, but moderate local input of anthropogenic $\mathrm{N}$ and organic matter; values from the other rías were within those reported for rocky-shore intertidal habitats in Galicia (Bode et al. 2006) but lower than those reported for tidal flats (Page \& Lastra 2003).

The selected macroalgae also provide estimates of long term inputs. Both species have a life span of several years (up to $16 \mathrm{yr}$ in Ascophyllum nodosum; Niell 1979) and have been shown to display increasing $\delta^{15} \mathrm{~N}$ values with increasing urban pressure (Bode et al. 2006, Viana et al. 2011) and WTP inputs (Savage \& Elmgren 2004). A. nodosum would be more sensitive to anthropogenic $\mathrm{N}$ because it is restricted to estuarine areas, whereas Fucus vesiculosus can be found in a wide range of habitats (Bode et al. 2006, Viana et al. 2011). However, even for $A$. nodosum, the measured $\delta^{15} \mathrm{~N}$ values did not reach those observed in the more populated ría of A Coruña (Bode et al. 2006), again suggesting low inputs of anthropogenic $\mathrm{N}$. The relatively high $\delta^{15} \mathrm{~N}$ of $F$. vesiculosus in O Barqueiro compared to Viveiro may indicate local, but low inputs of urban residual water or sewage. These results agree with the general decrease in $\delta^{15} \mathrm{~N}$ measured in Fucus spp. from Galician rías since 1990 (Viana et al. 2011) that could be attributed to an improvement in WTP facilities along the coast.

Considering all compartments analysed, the inputs of the different sources of nutrients and organic matter for all rías may be considered comparable. The linear relationship between $\delta^{15} \mathrm{~N}$ and $\delta^{13} \mathrm{C}$ (Fig. 7) did 
not vary significantly among rías, suggesting a balanced input of essentially the same $\mathrm{C}$ and $\mathrm{N}$ sources. The patterns of the areas defined by $\delta^{15} \mathrm{~N}$ and $\delta^{13} \mathrm{C}$ plots, however, indicate important differences. The results indicate that overall trophic complexity (including number of trophic levels and diversity of carbon sources) decreased from west to east. Ortigueira, for instance, displayed a large variety of sources, as indicated by the large range in $\delta^{15} \mathrm{~N}$ and $\delta^{13} \mathrm{C}$ that can be attributed to its large salt marsh area (Xunta de Galicia 2009). However, most samples in this ría were closely packed around the centroid of the distribution, indicating low trophic diversity and, therefore, marginal influence of the additional salt marsh sources. In contrast, Viveiro displayed a small range of $\delta^{15} \mathrm{~N}$ and $\delta^{13} \mathrm{C}$ but samples were more evenly distributed than in the other rías, revealing higher trophic diversity likely due to inputs at small spatial or temporal scales. O Barqueiro was an intermediate case with measures of trophic diversity in between those of the other rías. Notwithstanding the representativeness of samples characterising nutrient sources at very different time scales (days to years) in our plots, the derived metrics support the general homogeneity of biogeochemical and trophic processes in these rías, along with the generally low impact of anthropogenic sources.

\section{CONCLUSIONS}

The strong influence of marine nutrients, low urban population pressure and low industrialisation have cushioned the studied northern Galician rías from large impacts of anthropogenic nutrients as also found in other Galician rías (Bode et al. 2006) and Portuguese estuaries (Castro et al. 2007). However, there are indications of potential threats to these pristine environments, e.g. the extreme stable isotope signatures that can be associated with the most populated areas. The combination of measurements of nutrient stocks and stable isotope composition in compartments characterised by different renewal times allowed for more complete estimations of the importance of the various nutrient and organic sources for coastal food webs.

Acknowledgements. The collaboration of the crew of RV 'Lura' greatly facilitated water and sediment sampling. J. Lorenzo, V. Escourido, A. Roura, A. Rodríguez-Riveiros and E. Rey helped with the collection of seston and intertidal specimens. We thank 3 anonymous reviewers for their comments and suggestions. This research was partly supported by projects INTERESANTE (CTM2007-62546-C03) and ANILE (CTM2009-08396) of the Ministerio de Ciencia e Innovación (Spain).

\section{LITERATURE CITED}

Alvarez I, Ospina-Alvarez N, Pazos Y, deCastro M and others (2009) A winter upwelling event in the Northern Galician Rias: frequency and oceanographic implications. Estuar Coast Shelf Sci 82:573-582

Alvarez I, Ospina-Alvarez N, deCastro M, Varela M, GomezGesteira M, Prego R (2010) Poleward intrusion in the northern Galician shelf. Estuar Coast Shelf Sci 87:545-552

Álvarez-Salgado XA, Gilcoto M (2004) Inferring nitrification rates with an inverse method in a coastal upwelling system, Ría de Vigo (NW Spain). Mar Ecol Prog Ser 276:3-17

Álvarez-Salgado XA, Rosón G, Pérez FF, Pazos Y (1993) Hydrographic variability off the Rías Baixas (NW Spain) during the upwelling season. J Geophys Res 98(C8):14447-14455

Álvarez-Salgado XA, Labarta U, Fernández-Reiríz MJ, Figueiras FG and others (2008) Renewal time and the impact of harmful algal blooms on the extensive mussel raft culture of the Iberian coastal upwelling system. Harmful Algae 7:849-855

Barton ED (1998) Eastern boundary of the North Atlantic: Northwest Africa and Iberia. In: Robinson AR, Brink KH (eds) The sea, Vol 11. John Wiley \& Sons, London, p 633-657

Bode A, Varela M, Barquero S, Alvarez-Ossorio MT, González N (1998) Preliminary studies on the export of organic matter during phytoplankton blooms off La Coruña (North Western Spain). J Mar Biol Assoc UK 78:1-15

Bode A, Alvarez-Ossorio MT, Varela M (2006) Phytoplankton and macrophyte contributions to littoral food webs in the Galician upwelling estimated from stable isotopes. Mar Ecol Prog Ser 318:89-102

Castro P, Valiela I, Freitas H (2007) Eutrophication in Portuguese estuaries evidenced by $\delta^{15} \mathrm{~N}$ of macrophytes. Mar Ecol Prog Ser 351:43-51

Cifuentes LA, Sharp JH, Fogel ML (1988) Stable carbon and nitrogen isotope biogeochemistry in the Delaware estuary. Limnol Oceanogr 33:1102-1115

Cook PLM, Revill AT, Clementson LA, Volkman JK (2004) Carbon and nitrogen cycling on intertidal mudflats of a temperate Australian estuary. III. Sources of organic matter. Mar Ecol Prog Ser 280:55-72

Dale AW, Prego R (2002) Physico-biogeochemical controls on benthic-pelagic coupling of nutrient fluxes and recycling in a coastal upwelling system. Mar Ecol Prog Ser 235:15-28

Dale AW, Prego R, Millward GE, Gomez-Gesteira M (2004) Transient oceanic and tidal contributions to water exchange and residence times in a coastal upwelling system in the NE Atlantic: the Pontevedra Ria, Galicia. Mar Pollut Bull 49: 235-248

Daskin JH, Calci KR, Burkhardt W, Carmichael RH (2008) Use of $\mathrm{N}$ stable isotope and microbial analyses to define wastewater influence in Mobile Bay, AL. Mar Pollut Bull 56: 860-868

Deudero S, Cabanellas M, Blanco A, Tejada S (2009) Stable isotope fractionation in the digestive gland, muscle and gills tissues of the marine mussel Mytilus galloprovincialis. J Exp Mar Biol Ecol 368:181-188

Figueiras FG, Labarta U, Fernández Reiriz MJ (2002) Coastal upwelling, primary production and mussel growth in the Rías Baixas of Galicia. Hydrobiologia 484:121-131

Fry B, Wainright SC (1991) Diatom sources of ${ }^{13} \mathrm{C}$-rich carbon in marine food webs. Mar Ecol Prog Ser 76:149-157

Gago J, Alvarez-Salgado XA, Nieto-Cid M, Brea S, Piedracoba S (2005) Continental inputs of C, N, P and Si species to the Ría de Vigo (NW Spain). Estuar Coast Shelf Sci 65:74-82

Gómez-Gesteira M, Moreira C, Alvarez I, de Castro M (2006) Ekman transport along the Galician coast (northwest Spain) calculated from forecasted winds. J Geophys Res 111: C10005, doi:10.1029/2005JC003331 
Graham MC, Eaves MA, Farmer JG, Dobson J, Fallick AE (2001) A study of carbon and nitrogen stable isotope elemental ratios as potential indicators of source and fate of organic matter in sediments of the Forth Estuary, Scotland. Estuar Coast Shelf Sci 52:375-380

Grasshoff K, Ehrhardt M, Kremling K (1983) Methods of seawater analysis. Verlag Chemie, Weinheim

Holmes RM, McClelland JW, Sigman DM, Fry B, Peterson BJ (1998) Measuring ${ }^{15} \mathrm{~N}-\mathrm{NH}_{4}{ }^{+}$in marine, estuarine and fresh waters: an adaptation of the ammonia diffusion method for samples with low ammonium concentrations. Mar Chem 60: 235-243

Jacob U, Mintenbeck K, Brey T, Knust R, Beyer K (2005) Stable isotope food web studies: a case for standardized sample treatment. Mar Ecol Prog Ser 287:251-253

Jennings S, Maxwell TAD, Schratzberger M, Milligan SP (2008) Body-size dependent temporal variations in nitrogen stable isotope ratios in food webs. Mar Ecol Prog Ser 370:199-206

Keefe CW (1994) The contribution of inorganic compounds to the particulate carbon, nitrogen, and phosphorus in suspended matter and surface sediments of Chesapeake Bay. Estuaries 17:122-130

Kendall C (1998) Tracing nitrogen sources and cycling in catchments. In: Kendall C, McDonnell JJ (eds) Isotope tracers in catchment hydrology. Elsevier, St. Louis, MO, p 519-576

Kwak TJ, Zedler JB (1997) Food web analyses of southern California coastal wetlands using multiple stable isotopes. Oecologia 110:262-267

Layman CA, Arrington DA, Montaña CG, Post DM (2007) Can stable isotope ratios provide for community-wide measurements of trophic structure? Ecology 88:42-48

Liu KK, Kaplan IR (1989) The eastern tropical Pacific as a source of ${ }^{15} \mathrm{~N}$-enriched nitrate in seawater off southern California. Limnol Oceanogr 34:820-830

Lorenzo F, Alonso A, Pellicer MJ, Pagés JL, Pérez-Arlucea M (2007) Historical analysis of heavy metal pollution in three estuaries on the north coast of Galicia (NW Spain). Environ Geol 52:789-802

Lorrain A, Paulet YM, Chauvaud L, Savoye N, Donval A, Saout $\mathrm{C}$ (2002) Differential $\delta^{13} \mathrm{C}$ and $\delta^{15} \mathrm{~N}$ signatures among scallop tissues: implications for ecology and physiology. J Exp Mar Biol Ecol 275:47-61

Mariotti A, Germon JC, Hubert P, Kaiser P, Letolle R, Tardieux A, Tardieux P (1981) Experimental determination of nitrogen kinetic isotope fractionation: some principles; illustration for the denitrification and nitrification processes. Plant Soil 62:413-430

McClelland JW, Valiela I (1998) Changes in food web structure under the influence of increased anthropogenic nitrogen inputs to estuaries. Mar Ecol Prog Ser 168:259-271

McKinney RA, Oczkowski AJ, Prezioso J, Hyde KJW (2010) Spatial variability of nitrogen isotope ratios of particulate material from Northwest Atlantic continental shelf waters. Estuar Coast Shelf Sci 89:287-293

Neveux J, Panouse M (1987) Spectrofluorometric determination of chlorophylls and pheophytins. Arch Hydrobiol 109:567-581

Niell FX (1979) Sobre la biologia de Ascophyllum nodosum (L.) Le Jol. en Galicia. III. Biometria, crecimiento y produccion. Invest Pesq (Spain) 43:501-518

Olli K, Riser CW, Wassman P, Ratkova T, Arashkevich E, Pasternak A (2001) Vertical flux of biogenic matter during a Lagrangian study off the NW Spanish continental margin. Prog Oceanogr 51:443-466

Ospina-Alvarez N, Prego R, Álvarez I, deCastro M and others (2010) Oceanographical patterns during a summer upwelling-downwelling event in the Northern Galician Rias: comparison with the whole Ria system (NW of Iberian Peninsula). Cont Shelf Res 30:1362-1372

Paerl HW, Valdes LM, Peierls BL, Adolf JE, Harding LW (2006)

Editorial responsibility: Katherine Richardson,

Copenhagen, Denmark
Anthropogenic and climatic influences on the eutrophication of large estuarine ecosystems. Limnol Oceanogr 51: 448-462

Page HM, Lastra M (2003) Diet of intertidal bivalves in the Ría de Arosa (NW Spain): evidence from stable $\mathrm{C}$ and $\mathrm{N}$ isotope analysis. Mar Biol 143:519-532

Peterson BJ, Fry B (1987) Stable isotopes in ecosystem studies. Annu Rev Ecol Syst 18:293-320

Phillips DL, Gregg JW (2003) Source partitioning using stable isotopes: coping with too many sources. Oecologia 136:261-269

Piedracoba S, Nieto-Cid M, Souto C, Gilcoto M and others (2008) Physical-biological coupling in the coastal upwelling system of the Ría de Vigo (NW Spain). I: In situ approach. Mar Ecol Prog Ser 353:27-40

Piola RF, Moore SK, Suthers IM (2006) Carbon and nitrogen stable isotope analysis of three types of oyster tissue in an impacted estuary. Estuar Coast Shelf Sci 66:255-266

Prego R (1994) Nitrogen interchanges generated by biogeochemical processes in a Galician ria. Mar Chem 45:167-176

Prego R, Bao R (1997) Upwelling influence on the Galician coast: silicate in shelf water and underlying surface sediments. Cont Shelf Res 17:307-318

Prego R, Vergara J (1998) Nutrient fluxes to the Bay of Biscay from Cantabrian rivers (Spain). Oceanol Acta 21:271-278

Prego R, Barciela MC, Varela M (1999) Nutrient dynamics in the Galician coastal area (Northwestern Iberian Peninsula): Do the Rias Bajas receive more nutrient salts than the Rias Altas? Cont Shelf Res 19:317-334

Rio-Barja FJ, Rodríguez-Lestegás F (1996) Os rios galegos: morfoloxía e rexime. In: Consello da Cultura Galega (ed) As augas de Galicia. Consello da Cultura Galega, Santiago de Compostela, p 149-211

Savage C, Elmgren R (2004) Macroalgal (Fucus vesiculosus) $\delta^{15} \mathrm{~N}$ values trace decrease in sewage influence. Ecol Appl 14:517-526

Schmidt SN, Olden JD, Solomon CT, Vander Zanden MJ (2007) Quantitative approaches to the analysis of stable isotope food web data. Ecology 88:2793-2802

Silva N, Vargas CA, Prego R (2011) Land-ocean distribution of allochthonous organic matter in surface sediments of the Chiloé and Aysén interior sea (Chilean Northern Patagonia). Cont Shelf Res 31:330-339

Thornton SF, McManus J (1994) Application of organic carbon and nitrogen stable isotope and $\mathrm{C} / \mathrm{N}$ ratios as source indicators of organic matter provenance in estuarine systems: evidence from the Tay Estuary, Scotland. Estuar Coast Shelf Sci 38:219-233

Tucker J, Sheats N, Giblin AE, Hopkinson CS, Montoya JP (1999) Using stable isotopes to trace sewage-derived material through Boston Harbor and Massachusetts Bay. Mar Environ Res 48:353-375

Varela MM, Bode A, González N, Rodríguez C, Varela M (2003) Fate of organic matter in the Ría de Ferrol (Galicia, NW Spain): uptake by pelagic bacteria vs. particle sedimentation. Acta Oecol 24:S77-S86

Varela M, Prego R, Pazos Y (2004) Vertical biogenic particle flux in a western Galician ria (NW Iberian Peninsula). Mar Ecol Prog Ser 269:17-32

Viana IG, Fernández JA, Aboal JR, Carballeira A (2011) Measurement of $\delta^{15} \mathrm{~N}$ in macroalgae stored in an environmental specimen bank for regional scale monitoring of eutrophication in coastal areas. Ecol Indic 11:888-895

Vidal M, Duarte CM, Sanchez MC (1999) Coastal eutrophication research in Europe: progress and imbalances. Mar Pollut Bull 38:851-854

Xunta de Galicia (2009) Estudo preliminar das Rías Altas: oceanografía e bioloxía das zonas de interese marisqueiro das rías de Ribadeo, Foz, Viveiro, O Barqueiro e Ortigueira, Vol 8. Consellería do Mar, Santiago de Compostela

Proofs received from author(s): September 5, 2011 